\title{
TEACHING PRONUNCIATION BY WRITING PHONETIC SYMBOLS FOR PRONUNCIATION 1 CLASS \\ (A CASE STUDY AT THE EMINENCE ENGLISH COURSE)
}

\author{
Agung Priyanto
}

\begin{abstract}
The aim of this study is to describe the process of teaching pronunciation by writing phonetic symbols at The Eminence English Course Pare. Those are including of: the process of teaching pronunciation by writing phonetic symbols at The Eminence, the students' response toward the process of teaching pronunciation, and tutor solution of the problems which are faced by students. Qualitative was selected as a research approach; observation was used to collect some information about pronunciation program. The instrument used for collecting documents which is related to pronunciation program was documentation, it was kind of module book. The questionnaire was used to get students' perception in teaching learning process at pronunciation program. The result of this study showed that the process of teaching phonetic symbols at The Eminence had been supported by syllabus and lesson plan although it was not written yet structurally, the material was taken from module book, the media is using whiteboard, speaker, and Oxford dictionary. The method which was used was direct or natural method, the technique which was applied in the class was reading aloud technique. The evaluation of this program was taken on Sunday at the second week by giving written test. From the result about the students' perception was known that students had problems in pronunciation. It is word connection. Tutor solves this problem by giving word connection material.
\end{abstract}

Key word: phonetic symbols, pronunciation, teaching pronunciation

\section{INTRODUCTION}

Pronunciation is one of the most neglected aspects of English language teaching. In fact, almost all English language teachers get students to study grammar and vocabulary, practice functional dialogues, take part in productive skill activities and become competent in listening and reading.

According to Kelly (2000: 13), "the fact that pronunciation tends to suffer from neglect may not be due to teachers lacking interest in the subject but rather to a feeling of doubts as to how to teach it". Nowadays, students are more likely to imitate what they hear (Slattery and Willis, 2001). Second, as claimed by Nixon and Tomlinson, "it is much easier to teach and correct pronunciations in the early stages of developing students rather than improving the time that is made worse later pronunciation errors (Nixon and Tomlinson, 2005: 9).

Akmajian and others (1995:66) emphasize on the importance of phonetic symbols that includes a special symbol or special combination of symbols which 
may represent each significant speech sound of a language; therefore, this transcription system overcomes the shortcomings of the current English alphabet. In this case, the writer is interested in describe about the process of teaching pronunciation by writing phonetic symbol at The Eminence English Course Pare.

The purpose to do these researches is: (1) to describe the process of teaching pronunciation by writing phonetic symbol at The Eminence English Course Pare; (2) To describe the response of the students towards the process teaching pronunciation by writing phonetic symbol (in the term of students' difficulties, perception on the teaching learning process, and the advantages); (3) To describe the tutor solution of the problems which are faced by students (in the term of problem identification and solution).

\section{METHODOLOGY}

In this research, the researcher used descriptive qualitative. This research will describe about the process of teaching pronunciation by writing phonetic symbols. The settings of this research were the students of The Eminence English Course Pare who had been joining the class 2019 for approximately two weeks chronologically. The observation starts from May $10^{\text {th }} 2019$ until May $19^{\text {th }} 2019$. It is located in Jl. Brawijaya No102B, Mangunrejo, Tulungrejo, Pare, Kediri. Key of informant for this study was people who related to pronunciation program, they were; the manager was named Mr. Dino Abdurrohim Suryo, and the student was named Yudi Harianto.

To collect the data the researcher used instrument such as interview, observation, documentation, and questionnaire. Interview was used for collecting data about the process of teaching phonetic symbols at The Eminence. Observation was used to collect some information about pronunciation program. Documentation was used for collecting documents which is related to pronunciation program. Questionnaire was used to get students' perception in teaching learning process at pronunciation program.

The data analysis was based on three concurrent flows of activities, they were: data reduction, data display, and verification. Data reduction was used to classify, direct, and organize the data obtained from interviews, observations, and documentations. Data display was used to present the data in the form of brief description, charts, relationship between categories, and so on. Verification was used to present preliminary conclusion which is still tentative and needed evidence to support strong data collection.

\section{FINDING AND DISCUSSION}

Finding and discussion consist of three aspects, they are the process of teaching pronunciation by writing phonetic symbol, students' response, and tutor's solution.

\section{The Process of Teaching Pronunciation by Writing Phonetic Symbol}

The finding that found in teaching process of teaching pronunciation by writing phonetic symbol was divided into some parts; they were syllabus, lesson plan, method, technique, media, material, teaching learning process, and evaluation model. 
Syllabus which was found in The Eminence English course was different with the syllabus in formal education. Syllabus at The Eminence English Course is different from syllabus in formal school. The syllabus is in the form of a module book. Hutchinson and Waters (1987) in Popescu (2011:104) define syllabus as a statement of what is to be learnt which reflects of language and linguistic performance.

The lesson plan at The Eminence was different from lesson plan in educational institution where the lesson plan was simpler and used in every period with the same pattern. It might cause of the tutor who did not have background from educational courses and it made the less knowledge about the lesson plan. According to Singh (2010: 129) a lesson plan is a practical outline of a topic to be taught in a period.

The method which was applied in the class was the tutor asked students in the term of interview where the students should answer in English and did not allowed speaking Indonesia. It can be concluded that the name of the method is direct or natural method. Freeman (2000: 23) says that direct method or sometimes called as natural method is a method where there is no translation is allowed. It means that all students should speak English as the second language.

In the pronunciation class, reading aloud technique was used to teach the students. The tutor was consistent to use this technique during the period. Diane Larsen-Freeman, in her book Techniques and Principles in Language Teaching (1986:26-27) provides expanded descriptions of some common/typical techniques closely associated with the Direct Method. The listing here is in summary form only: 1) Reading Aloud,2) Question and Answer Exercise, 3) Student SelfCorrection, 4) Conversation Practice, 5) Fill-in-the-blank Exercise, 6) Dictation, and 7) Paragraph Writing. From the explanation was known that tutor in The Eminence English Course use Reading Aloud technique in teaching pronunciation program. Tutor use Reading Aloud technique in delivering material like phonetic symbol, pronouncing "to", pronouncing "ed", pronouncing "s or z", and the other material.

From the findings, the media which were used in pronunciation program were whiteboards, speakers, and Oxford dictionary. Tutor used speakers to teach listening students, so he could tell which words contain British accents, and which words contain American accents. Tutor used white board to give new material. Tutor used screen audio to train their visual. And Tutor used Oxford dictionary in teaching phonetic symbol material. Arsyad (2002:3) says that media are aid which is needed to support some of activities in the world; media includes graphics, photographic, or electronic aid to absorb, process, and rearrange visual and information. According to Ministry of National Education (2009: 6) there are seven media which is used by teacher in the classroom, they are: pictures; relia or real object; charts, posters, and cartoon; blackboard or whiteboard; audio media; over head projector (OHP); and LCD projector. Arsyad (2002: 4) says that Media delivered the contents of learning materials consisting of, among others: books, tape recorders, recorded, video cameras, video recorders, films, slides (pictures frame), photos, pictures, graphics, television, and computers. 
The material which was used by the tutor comes from module book and internet. All students who have joined the pronunciation program will get a module book. Even though all students got the module book, the students must write the tutor's explanation on their note book. The material which was used is always same from period to period. Tutor just adds some motivation so that student will feel enthusiastic in learning pronunciation. Material in teaching can help teacher in teaching and learning process. Material is an organized body of knowledge structured and arranged around a key concept. It means that materials are collection of knowledge, which is arranged based on the objectives, the relevant and the needs as stated as in the curriculum and syllabus (Dubin \& Olshtain, 1992:29).

The teaching learning process which was found in pronunciation program at The Eminence English Course was the tutor guided the students to improve their ability in pronunciation. Teaching learning process was At $8.00 \mathrm{am}$, he leads students to pray together. The students sit on the floor. The tutor writes and gives new material about pronunciation at the white board. After students finished writing, the tutor reviewed the material that had been taught. Sometimes tutor give tongue twister so that the students will be enthusiastic about learning. Then tutor give new material. While giving new material, tutor read aloud the material. Then students repeat what the tutor says. If students pronunciation still weak, tutor read aloud again until students' pronunciation is good enough. Then they pronounce the material one by one. Before closing the program, the tutor asks whether the students have question or not. The tutor inform lesson in the next meeting. The class is dismissed as soon as the tutor greets them. Fraenkel (1984) said that there are two main steps to learning how to pronounce a language:

1. Receptive/list stage. In this stage, we learn to differentiate the significant sounds and pattern by listening to the language.

2. Productive/speaking stage. By this stage, we learn to speak or to produce what we have learned before.

Based on the theory, learning pronunciation at The Eminence was a productive stage. Students learn to speak or to produce what we have learned at The Eminence English Course. Evaluation model for pronunciation 1 program was written test. The final test is taken after two weeks the students learnt about pronunciation 1. The test consisted of which had been learnt in pronunciation 1. Test is usually held at the last meeting. The model test is written test in pronunciation 1 program. Students who have a score of more than 80 can continue to the pronunciation 2 program. If students' score less than 80 , they can also continue the pronunciation 2 program by doing remedial test. The result of the test will be announced at the office. Brown (2004:3) stated that a test, in simple terms, is a method of measuring a person's ability, knowledge, or performance in a given domain. A test is first a method. It is an instrument - a set of techniques, procedures, or items - that requires performance on the part of test-taker. Second, a test must measure. Some tests measure general ability, while others focus on very specific competencies or objectives. A test measured an individual's ability, knowledge, or performance. 
Based on the theory, the evaluation model which was used in pronunciation program written test. The test consisted of knowledge which had been learnt in pronunciation 1.

\section{Students' Response}

Students' response consist of three aspects, they are students' difficulties, students' perception on teaching learning process, and the advantages.

\section{Students' Difficulties}

The students said that problem that often faced him in pronunciation is mother tongue interface. Students often have difficulty in pronouncing several vowels because of mother tongue interface. They felt difficult to distinguish sound from vowel one and other vowel. The adults vocal musculature is set to pronounce foreign sounds with an accent (Yule; O'Connor, 2003) reported that the main problem of English pronunciation is to build a new set of sounds corresponding to the sounds of English, and to break down the arrangement of sounds which the habits and the systems of our LI have strongly built up. And that means we use new ways of hearing and new ways of using our organs of speech. So it is too difficult to change such habits which a learner has obtained since his childhood or at least it needs very long years to be changed and after also very long time and regular practice, and all that is linked to a certain age of the learner. So the points mentioned above altogether share the concept that the learners confuse such sounds and replace each of them with other sounds that are said to be the nearest ones to them (O'Connor, 2003).

\section{Students' Perception in the Teaching Learning Process}

Students had their own perception about the teaching learning process, whether it was a good perception or bad perception. The students' perception in teaching learning process was gotten from interview with one of the student and from the questionnaire. From the data was gotten that they feel fun in learning pronunciation. Tutors slip songs in delivering material. Before entering the new material the tutor always reviews all the material that has been taught before. So that the students will memorize the material, and the tongue will be easy to say the English words. For students who really understand the phonetic symbol material is an advantage for them. By understanding the phonetic symbol, students will be able to pronounce the word well through the Oxford media dictionary.

By all means, songs are not only powerful to young people but also affect their feelings and energy levels. Without even thinking about songs, people use songs and other musical sounds to create desired moods to make them happy. Songs often referred to music are something to enjoy in movement and dance, to energize, to bring back powerful memories, to help people relax and even to focus. Throughout history, people have used sounds for different purposes, and this has certainly enhanced their learning and living in many different ways. Many people consider songs to be a very important part of their lives. However it is not used as often at work and in school (Millington, 2011:134-135). 


\section{The Advantages}

The purpose of the students to follow pronunciation program was. The main goal of pronunciation 1 program is student will be able to speak as good as the native speaker. Student's pronunciation will look so good and doesn't look rigid. Students did not speak word by word anymore. Students will feel easy and fluent in pronouncing English word. If the students understand the phonetic symbol material, we will be able to say words that we have never found before through the Oxford dictionary.

\section{Tutor's Solution}

Tutor's solution consist of two aspects, they are problem identification and solution.

\section{Problem Identification}

The problems which happen would be identified by the tutor whether this is the big problems or not. If the problem was about the students who did not understand about the material or the tutor's explanation, the tutor could solve it by himself. If there is a big problem, it needs to discuss formally in the meetings with all staffs of The Eminence English Course. Tutor said that problem tutors explain the problems that have appeared from students are lack of motivation. Some students were not enthusiastic in taking the pronunciation program 1. Students do not join the class at certain material times taught. For those who are enthusiastic in taking the pronunciation program there are no significant problems. For those who are enthusiastic about taking the pronunciation program, their pronunciation skills will increase significantly. However, more recent research suggests that environment and motivation may be more important factors in the development of native-like pronunciation than is age at acquisition (Marinova-Todd, Marshall, \& Snow, 2000). Student also said that problem appeared while joining pronunciation program. Student often speaks word by word. Then, their pronunciation looks rigid. To solve this problem, the student must be serious in understanding the word connection material that has been given tutor.

\section{Solution}

Solution was given after the problem has been identified. The solution might give advantage for the students without giving the disadvantages to the course. If students do not join the pronunciation program, tutor will ask what they are doing so that they do not take part in the program. Tutor also gives a little motivation to students so that they are enthusiastic in taking the pronunciation program. In this case, the tutor is required to be patient in giving motivation to the student. Learning English could be very challenging for college students. There are many factors that might cause the students' low competence in English. According to (Pintrich \& Schunk, 2002) said that many people consider motivation, which refers to the process whereby goal directed activity is instigated and sustained. Besides, if student faced problem like word connection, students must really learn the word connection material that tutors have taught. 


\section{CONCLUSION}

1. The process of teaching pronunciation by writing phonetic symbol is supported by sets of equipment in learning such as (1) syllabus, (2) lesson plan, (3) method, (4) media, and (6) material. Although syllabus and lesson plan were available in that course, but they were not written structurally yet in this course. Material was taken from module book and internet which is rewritten by the tutor. The application of method and technique which was used in the class had been suitable with the theory. This program used direct or natural method and reading aloud technique in the class. Media which were used in pronunciation program were whiteboards, speakers, and Oxford dictionary. Tutor used speakers to teach listening students, so he could tell which words contain British accents, and which words contain American accents. Tutor used white board to give new material. Tutor used screen audio to train their visual. And Tutor used Oxford dictionary in teaching phonetic symbol material. The teaching learning process had been run well start from $8.00 \mathrm{am}$ to $9.45 \mathrm{am}$. The evaluation of this program was taken at the last meeting of pronunciation 1 program. The form of the test is written test. Students who have a score of more than 80 can continue to the pronunciation 2 program. If students' score less than 80 , they can also continue the pronunciation 2 program by doing remedial test.

2. The response of students toward the teaching of pronunciation process were consist of three terms, they are (1) students' difficulties, (2) students' perception on teaching learning process, and (3) the advantages which can be taken by following this program. The first was about students' difficulties. The students said that problem that often faced him in pronunciation is mother tongue interface. Students often have difficulty in pronouncing several vowels because of mother tongue interface. They felt difficult to distinguish sound from vowel one and other vowel. For students' perception in teaching learning process, they said that they feel fun in learning pronunciation. Tutors slip songs in delivering material. The main goal of pronunciation 1 program is student will be able to speak as good as the native speaker.

3. All staff of The Eminence discuss in general meeting. After identified the problems, the solution can be given. For students problem. If students do not join the pronunciation program, we ask what they are doing so that they do not take part in the program. We also give a little motivation to students so that they are enthusiastic in taking the pronunciation program. In this case, the tutor is required to be patient in giving motivation to the student. Learning English could be very challenging for college students.

\section{REFERENCES}

Akmajian, A., Demers, R., Farmer, K. A., and Harnish, M. R. (1995). Linguistics: An Introduction to Language and Communication. New Delhi: Hall of India, 15, 21, 427.

Arsyad, A. 2002. Media Pembelajaran. Jakarta: Raja Grafindo Persada. 
Brown, H. D. 2004. Language Assessment: Principles and Classroom Practices. New York: Longman.

Dubin, F., \& Olshtain, E. 1992. Course Design: Developing Program and Materials for Language Learning. Cambridge: Cambridge University Press.

Fraenkel, A. (1984) Survey review pronunciation. Eriglish Language Teaching Journal, 38(1), 52-56.

Kelly, G. (2000). How to teach pronunciation (J. Harmer, Ed.). England: Longman.

Larsen-Freeman, D. (2000). Techniques and Principles in Language Teaching. Oxford: Oxford University Press

Marinova-Todd, S. H., Marshall, D. B., \& Snow, C. E. (2000). Three misconceptions about age and L2 learning. TESOL Quarterly, 34(1), 9-34. doi:10.2307/3588095, http://dx.doi.org/10.2307/3588095.

Millington, Neil T. (2011). Using Songs Effectively to Teach English to Young Learners. Journal of Language Education in Asia, 2011, 2(1), 134-141. Japan: Ritsumeikan Asia Pacific University.

Nixon, C., Tomlinson, M., 2005, Primary Pronunciation Box: Pronunciation games and activities for younger learners, Cambridge, Cambridge University Press.

O'Connor, J. D. (1980). Better English Pronunciation (2nd ed.). Cambridge: Cambridge University Press.

Popescu, Teodora., Pioariu, Radica., Herteg, Crina. 2011. Cross Disciplinary Approaches to the English Language. Cambridge: Cambridge Scholars.

Singh, Y. K. 2010. Micro Teaching. New Delhi: APH Publishing Corporation.

Slattery, Mary \& Jane Willis, English for Primary Teachers, New York; Oxford

Yule, G. (1996). The Study of Language (2nd ed.). Cambridge: Cambridge University Press. 